Portland State University

PDXScholar

Environmental Science and Management

Professional Master's Project Reports

Environmental Science and Management

Summer 2015

\title{
Rock Creek Restoration Macroinvertebrate Monitoring Report
}

Daniel Bedell

Portland State University

Follow this and additional works at: https://pdxscholar.library.pdx.edu/mem_gradprojects

Part of the Biodiversity Commons, Environmental Health and Protection Commons, Environmental Indicators and Impact Assessment Commons, and the Natural Resources Management and Policy Commons

Let us know how access to this document benefits you.

\section{Recommended Citation}

Bedell, Daniel, "Rock Creek Restoration Macroinvertebrate Monitoring Report" (2015). Environmental Science and Management Professional Master's Project Reports. 48.

https://pdxscholar.library.pdx.edu/mem_gradprojects/48

https://doi.org/10.15760/mem.45

This Project is brought to you for free and open access. It has been accepted for inclusion in Environmental Science and Management Professional Master's Project Reports by an authorized administrator of PDXScholar. Please contact us if we can make this document more accessible: pdxscholar@pdx.edu. 


\title{
Rock Creek Restoration Macroinvertebrate Monitoring Report
}

\author{
Clackamas County Water Environment Services
}

Watershed Health Education Program, 2011 - 2015

\begin{abstract}
Stream restoration is widely used to rebuild habitat for native fisheries, but it is not well understood how current habitat reconstruction practices affect biological diversity. Citizen Science programs have potential to provide supplemental macroinvertebrate data for effectiveness monitoring of reach-scale restoration projects but variability in training, experience and collection methods can make interpretation difficult. The Clackamas Water Environment Services Watershed Health Education Program (WHEP) is an example of a Citizen Science-based program actively collecting biological data from restored streams. The purpose of this project was to use WHEP student-collected data to detect benthic macroinvertebrate community responses to stream restoration practices. This report is not intended to establish biological criteria for restoration effectiveness monitoring but to provide a framework for promoting education and engagement using invertebrate monitoring programs.
\end{abstract}

Prepared by: Daniel Bedell - Masters of Environmental Management Project Prepared for: Clackamas County Water Environment Services - Watershed Health Education Program

Submitted: Summer 2015 


\section{Glossary of Terms:}

WES: Clackamas County Water Environment Services

LWD: Large Woody Debris

SWRP: Student Watershed Research Project

NCSD: North Clackamas School District

WHEP: Watershed Health Education Program

FFG: Functional Feeding Groups

OWEB: Oregon Watershed Enhancement Board

BMP: Best Management Practices

\section{Problem Statement}

\subsection{Restoration Effectiveness Monitoring}

Loss of freshwater habitat represents a major challenge to native fisheries around the world (Gleick 2003). Stream restoration has become a key part of Salmon recovery efforts in the US, costing $>\$ 1$ billion per year on average since 1990 (Berhardt 2005). The principle that restoring habitat complexity increases biodiversity, i.e. the "field of dreams hypothesis" (Palmer et al. 1997), is central to most restoration plans but few studies track how habitat reconstruction affects benthic community dynamics (Lepori et al. 2005; Roni et al. 2006). Most restoration monitoring focuses on physical responses to current practices and is known as postproject status reporting. The Oregon Watershed Enhancement Board (OWEB) requires post-project status reporting for all its restoration grants to determine if restoration projects were implemented according to their proposals in terms of manner, time and budget. Project-level effectiveness monitoring is distinct from post-project status reporting in that it involves collection of biological data to demonstrate the "accountability, success and value of restoration investments." (OWEB 2014). True restoration effectiveness monitoring involves collecting fish, periphyton or macroinvertebrate community data and is less commonly practiced because biological data is generally more difficult to collect (Roni 2002).

For reach scale restoration projects, benthic macroinvertebrates are monitored more often than fish or periphyton because of their limited mobility, 
accelerated life histories, relative abundance, and range of tolerances (Voshell et al. 1997). Additionally, macroinvertebrates are easy to collect while relatively course taxonomy can still reflect functional attributes of an ecosystem, such as habitat complexity and food availability (Bailey 2001). For these reasons, macroinvertebrates have become popular biological indicators used to measure environmental impacts in freshwater streams.

Macroinvertebrates are useful bioindicators of stream degradation because of their critical role stream ecosystem function (Wallace and Webster 1996), but have only recently been investigated as indicators of restoration effectiveness. A metaanalysis by Miller reviewed 53 publications to quantify macroinvertebrate responses to habitat restoration, but found most of these studies didn't report macroinvertebrate richness or density. Only 24 studies included a control stream from an unrestored channel, and only 8 of these studies had pre- and post-restoration macroinvertebrate monitoring data available. Of these 8 studies, one uses a replicated study design (Lester et al. 2007). Miller's meta-analysis suggests increased collection and reporting of macroinvertebrate data is needed to establish restoration performance criteria and make improvements to restoration science (Miller et al. 2009).

While post-project implementation status reporting is a common requirement for restoration grants, true effectiveness monitoring is achieved less often. Postproject status reporting involved descriptions of the work completed, pre- and postproject photographs, budget descriptions and recommendations for future projects. Effectiveness monitoring involves measuring biotic and abiotic changes to a stream to determine if restoration actions were effective in meeting biological objectives. Data used for restoration effectiveness monitoring must follow established protocols to produce statistically validated and repeatable results and is thus difficult to collect (OWEB 2014). The lack of available effectiveness monitoring data represents a barrier to the advancement of the applied science of stream restoration and its goals. 


\subsection{Citizen Science}

One potential source of data to fill this monitoring gap is Citizen Science, which empowers volunteers with tools to monitor the environment (Silvertown 2009). Volunteer macroinvertebrate monitoring groups have been active since the early 1990's and represent a large majority of citizen science data collected from US streams (Levy 1998, USEPA 1998). High variability in training, experience and collection methods among groups can make interpreting volunteer macroinvertebrate data challenging (Penrose and Call 1995). However, some studies have detected little difference among conclusions drawn from volunteer and professional data, suggesting volunteers can provide reliable ecological information when using standardized quantitative protocols (Fore 2001, Engel and Voshell 2002). This report represents an opportunity to use a before/after, control/impact (BACl) design to explore the use of Citizen Science in monitoring a stream restoration project with benthic macroinvertebrates.

\subsection{Macroinvertebrates as Indicators}

Benthic macroinvertebrates have been well established as indicators of stream health and habitat quality for several reasons. Due to their limited mobility, macroinvertebrates do not often travel between catchments, instead living complete life cycles within a reach scale area (Richards 1997). For this reason, macroinvertebrates are sensitive to reach scale disturbances such as construction activities associated with restoration projects. According to McCabe (2000), changes in macroinvertebrate communities in response to physical disturbances including stones being overturned, scraped or scoured can be detected between 15 and 420 days after the disturbance event. Conveniently, this length of time falls within the life cycles of many macroinvertebrate families. Additionally, collecting macroinvertebrates is more convenient and cost-effective than collecting biological 
data from fish of periphyton communities, because the equipment needed is cheaper and collection methods have a grab-sample convenience.

\subsection{Clackamas Macroinvertebrate Sampling}

In the lower Clackamas River Basin, ten professional and volunteer groups have been collecting macroinvertebrate data from streams since the 1990's. These data were collected using different sampling methods and invertebrate identifications were made at different taxonomic resolutions. Taxonomic resolutions among these data ranged from order to genus level, depending on the group that was operating. Additionally, some groups have been active for longer than other groups, creating a patchwork of macroinvertebrate data coverage in the basin. For some streams in the lower Clackamas River Basin, student-collected macroinvertebrate data represents the oldest data available among these groups (Cole 2013). In the lower Clackamas Basin, the single longest-running macroinvertebrate monitoring program is the Student Watershed Research Project (SWRP) administered by Portland State University (PSU). However, the SWRP uses order level macroinvertebrate identifications, which preclude detection of long-term ecological trends. For this reason, SWRP data is only used for educational purposes while genus-level data collected by professional groups is used for water quality monitoring and reporting.

One example of a lower Clackamas Basin monitoring program with moderate long-term trending potential is a K-12 macroinvertebrate sampling program that uses family-level identifications and has been active since 2010 (Cole 2013). The Watershed Health Education Program (WHEP) is a collaborative effort between Clackamas County Water Environment Services (WES) and North Clackamas School District schools to address public outreach and education Best Management Practices (BMPs) in the Clackamas Stormwater Management Plan (SWMP). The WHEP has allowed hundreds of high school students to sample aquatic macroinvertebrate communities from four streams in the Clackamas Basin over five years. Together, WHEP students and WES educators monitor aquatic life and use biological criteria to assess stream health for outreach and education purposes. 


\subsection{Community Partner Involvement}

My community partner is Clackamas WES, and I have worked closely with Gari Johnson, who is an administrator for the WHEP grant. Working with Gari, I have been leading field trips and classroom activities for WES as a WHEP instructor from 2010-2015. Gari was essential in facilitating the success of the project from the beginning. She coordinated bi-annual meetings between the different parties involved in this project in order to track progress and set goals for the future. Gari was our connection to Clackamas County and helped document the project with video updates for the Clackamas County Government TV Channel. She also helped to provide reimbursement for project expenditures such as sampling equipment.

My role in this project was that of an instructor, project coordinator, field technician, and research assistant. As an instructor, I helped develop and deliver curriculum on watershed health to students before field trips. Our curriculum involved information on physical and biological responses to watershed stressors such as urbanization, pesticides, herbicides and fertilizers in streams. I also trained teachers and students on family-level macroinvertebrate identification techniques before heading into the field. As a coordinator, I scheduled field trips to our study sites with teachers from different schools. I also helped transport collection gear between sites and classrooms. As a field technician, I was present at most field trips to help manage macroinvertebrate sampling activities to ensure accurate data was collected. As a research assistant, I helped develop predictions and analyze our macroinvertebrate data for long-term ecological trends by writing this report and creating the figures, tables, and maps contained herein.

\subsection{Need for Project}

During the course of this project, one of our study streams, Rock Creek, underwent a reach-scale restoration project. Since WHEP students completed four years of pre-project sampling, this represents a serendipitous opportunity to use 
student-collected data to track macroinvertebrate community responses to restoration with a BACI design experimental setup. Clackamas WES expressed interest in conclusions drawn from WHEP student data because the success of Rock Creek restoration project is of concern to the county. The Rock Creek Confluence project was completed without funding for professional effectiveness monitoring, so this project represents a chance to provide data that may be used for effectiveness monitoring at no extra cost to the county. We will be comparing long-term community trends from a nearby non-restored watershed in order to control for variability due to regional trends such as climate. If macroinvertebrate responses to restoration are detected at Rock Creek, the community partner may choose to supplement and enhance effectiveness monitoring with WHEP student-collected macroinvertebrate data in the future.

\section{Methods}

\subsection{Study Area}

To enable a BACI design, we selected study reaches from a restored stream and a nearby non-restored stream as our study and reference sites. Both streams are located in the lower Willamette basin in the Portland metropolitan area and were selected based on ease-of-access and proximity to local schools. The restored reach is located on Rock Creek, directly above its confluence with the Clackamas River (Figure 1).

Within Rock Creek's $9.4 \mathrm{mi}^{2}$ drainage, predominant land uses are urban (40\%) and agricultural (33\%) and forested (20\%) (WES 2014). The predominantly forested control reach is on Balch Creek at Lower Macleay Park within Forest Park in Portland, Oregon and is shown in Figure 1. Balch Creek drains $2.2 \mathrm{mi}^{2}$ of Forest Park, and was the only major water body in Portland that met Oregon water quality standards for bacteria, temperature and dissolved oxygen in 2005 (City of Portland 2005). Balch Creek also supports a small resident coastal cutthrout trout population, although it has not benefited from any significant restoration actions. (BES 2008). 


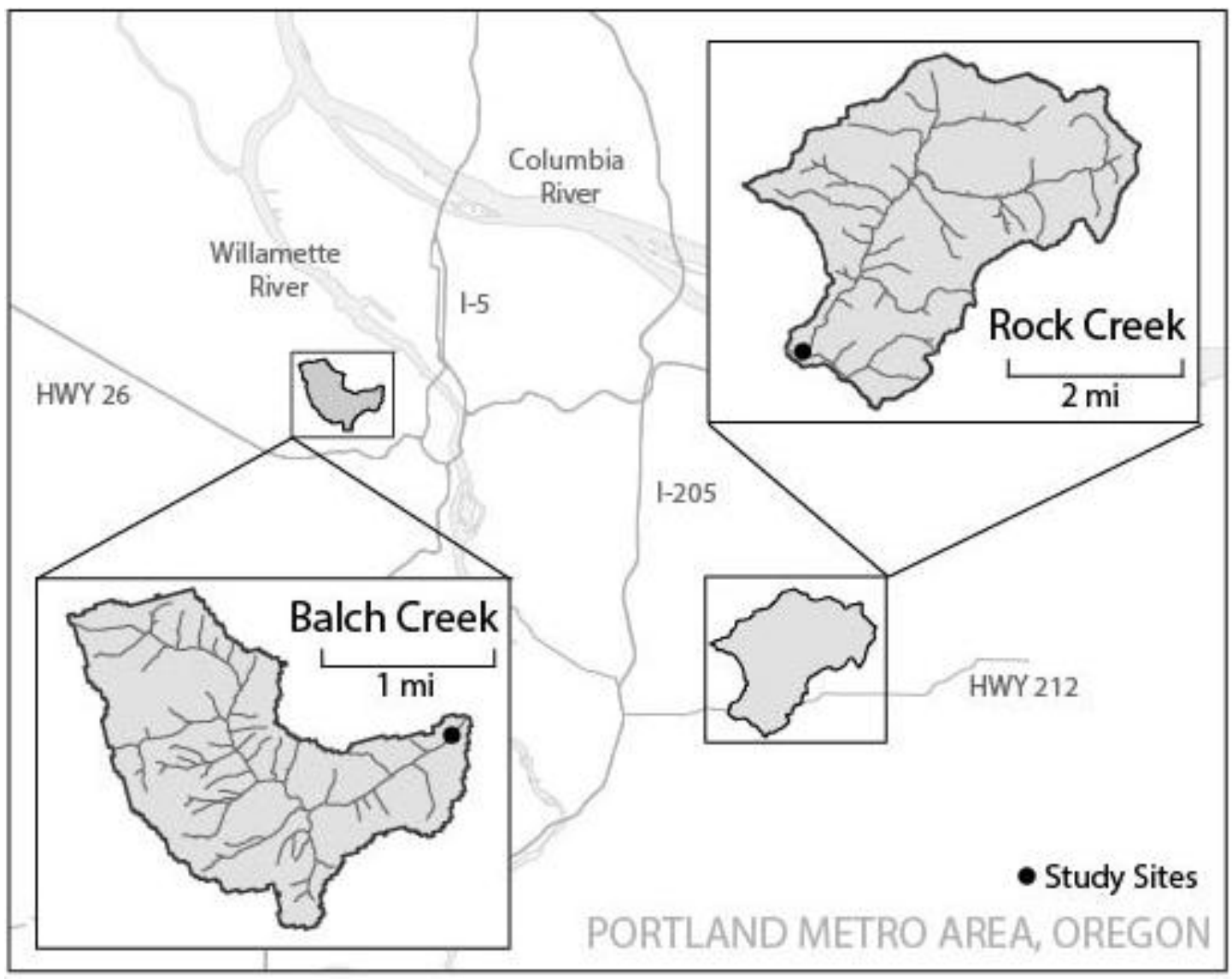

Figure 1: Map of study region including watershed boundary, stream network, and study sites on Balch Creek and Rock Creek in the Portland metropolitan region of Oregon.

In 2014, Clackamas WES partnered with Henderson Environmental Design Build Professionals to complete a $\$ 450,000$ restoration project on Rock Creek. The reach directly above Rock Creek's confluence with Clackamas River was identified as a high-priority restoration site because it offers a landscape position that would benefit Clackamas River fish species (WES 2012). The project scope included a 1600-foot reach and incorporated in-stream additions of large woody debris (LWD) and boulders, floodplain reconnection, erosion prevention and riparian revegetation to address a number of goals in the Rock Creek Watershed Action Plan (WES 2009). Figure 2 shows a concept map of the in-stream habitat modifications. 


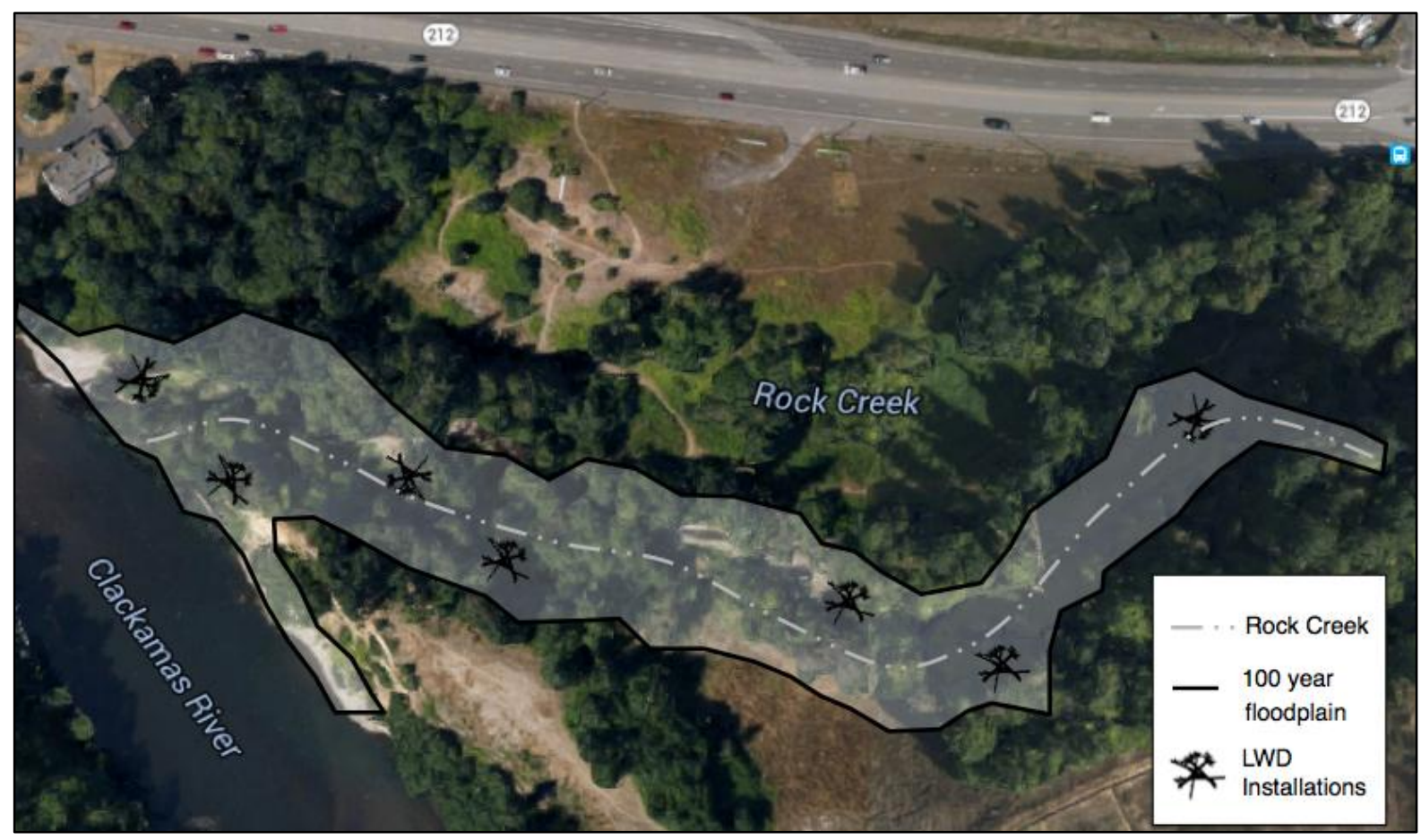

Figure 2: Concept map showing habitat modifications made to Rock Creek.

\subsection{Participants}

In our study, classes of students from Portland State University (PSU) and North Clackamas School District (NCSD) serve as a proxy for citizen science groups. Both of these groups received equal training before collecting data separately and concurrently. Students from PSU and NCSD followed the same field collection and identification methods and were supervised by Patrick Edwards or myself. Portland State University students involved in this study were predominately non-science majors and visited the control stream to collect macroinvertebrate data once per term as part of a lab-based science course. Students from PSU visited Balch Creek exclusively while students from NCSD only visited Rock Creek. Table 1 shows the differences in area sampled between Balch Creek and Rock Creek over the study period. 
Table 1: Summary of randomly sub-sampled area from which invertebrates were identified at Balch Creek and Rock Creek from Fall 2011 to Spring 2015. Note data is missing from Rock Creek in spring of 2014.

Table 1. Summary of area sampled $\left(\mathrm{ft}^{2}\right)$ from Balch Creek and Rock Creek in the Portland Metropolitan area between Fall 2011 to Spring 2015.

\begin{tabular}{r|r|rr}
\hline \multicolumn{2}{|c}{ Season } & Balch (PSU) & Rock (NCSD) \\
\hline $\mathbf{2 0 1 1}$ & Fall & 12 & 24 \\
& Spring & 9 & 17 \\
$\mathbf{2 0 1 3}$ & Fall & 9 & 22 \\
& Spring & 12 & 17 \\
$\mathbf{2 0 1 4}$ & Fall & 10 & 25 \\
& Spring & 12 & - \\
$\mathbf{2 0 1 5}$ & Fall & 10 & 18 \\
\hline
\end{tabular}

Data from the restored stream was collected as part of Clackamas Water Environment Services (WES) Watershed Health Education Program (WHEP). The WHEP program is meant to reach public outreach and education goals in the Clackamas Stormwater Management Plan, not to provide the county with supplemental water quality monitoring data. The basic approach of the WHEP program is to engage high school students with watershed health curriculum, followed by an inquiry-based field trip to a nearby stream. High school science teachers enrolled in the WHEP program provided classes of roughly 35 students for a field-based learning opportunity. High school students from NCSD visited Rock Creek once or twice per year and typically ranged from ages 15 to 18 . Before collecting data, participants from PSU and NCSD were trained in class sessions involving a briefing on family-level identification features. Training sessions were similar at NCSD and PSU and typically lasted 1.5 hours. At the end of each briefing session, each student was presented with preserved macroinvertebrates collected from the Willamette Valley and asked to visually identify one specimen of each major order, Ephemeroptera, Plecoptera, Trichoptera and Diptera. Students were then 
given a brief summary of the macroinvertebrate collection procedure before visiting a stream reach in the study area.

\subsection{Nonlethal field-based sampling}

Invertebrate data was collected on 1.5-hour field trips in the spring or fall from 2010-2015 during which students collected, sub-sampled and identified stream invertebrates. Portland State University and NCSD classes were broken into study groups of 3-5 students and were supervised in the field by experienced taxonomists. Student data collection groups followed a nonlethal field-based sampling method developed by Edwards (2005). To begin, students would locate a riffle section of the stream to collect samples from. Using a D-net, students collected 3 benthic samples from riffles, each representing $1 \mathrm{ft}^{2}$ area of streambed. All three samples were composited into a plastic tub representing $3 \mathrm{ft}^{2}$ of benthos. The composite was then emptied into a plastic container (manufactured by Akro Mils, $38 \mathrm{~cm} \times 24 \times \mathrm{xm} \times 6 \mathrm{~cm}$, part \#05905) that was used as a sorting tray. The container is divided into 18 cells that were sealed with silicone to prevent invertebrate movement between cells. Using a random number sheet, students randomly selected five cells to empty into ice-cube trays using turkey basters and featherweight tweezers. By selecting five cells out of the tray, students roughly sub-sampled $1 / 3^{\text {rd }}$ of the composite, representing a randomized $1 \mathrm{ft}^{2}$ area of benthos. Six cells were not sub-sampled because the corner cells were considerably larger than the rest. Ice-cube trays limited macroinvertebrate mobility and were filled with clean water to aid in sorting and identification. Invertebrates were sorted using magnifying glasses and ambient field light, and identified using the field guide, Stream Insects of the Pacific Northwest (Edwards 2008). All identifications were completed at the family level and included taxa from Ephemeroptera, Plecoptera, Trichoptera, and Diptera. Also included in this analysis were Gammaridae, Oligochaetes, Hydracarina and Planaria. Other invertebrate taxa represented $<1 \%$ of the total abundance and were not included in this analysis. 
At the end of each field trip, invertebrate data generated by each student group was recorded as abundance per $1 \mathrm{ft}^{2}$ and validated by an experienced taxonomist before living specimens were returned to the stream. This process was repeated by each group, yielding a number of samples equal to the number of student groups operating in each stream per season. Invertebrate data was not collected from Rock Creek during the restoration construction phase in spring 2014 due to liability concerns.

\subsection{Data Analysis}

From these data, we calculated macroinvertebrate community metrics commonly used to indicate stream condition. To enable a BACl design, Balch Creek is our control site, Rock Creek is our treatment site and the restoration project of spring to summer 2014 is the intervention. The use of restored and non-restored sites, along with data collected from before and after restoration activities is critical to building a $\mathrm{BACl}$ design for this study. We used line graphs to display ecological trends in macroinvertebrate community dynamics throughout the study period. We assessed mean taxa richness, mean invertebrate density, functional feeding group diversity, OWEB IBI score, long-lived density, short-lived density and Diptera density for each season and year. Family richness among the Ephemeroptera, Plecoptera and Trichoptera orders were averaged per season for each stream. Macroinvertebrate densities were measured in abundance per $\mathrm{ft}^{2}$ and were averaged per season for each stream. Functional attributes of macroinvertebrate families were classified using Merritt and Cummins (2008). Macroinvertebrate trends for both Rock Creek and Balch Creek were displayed on the same graph, in order to identify any large-scale regional changes that may influence stream productivity during the study period. In order to help the community partner interpret our results, we made a set of a priori predictions to describe the anticipated macroinvertebrate response to restoration at Rock Creek. 


\subsection{Predictions}

A priori predictions were made to help interpret the changes seen in Rock Creek, as some readers may not be familiar with benthic macroinvertebrate ecology. Predictions in Table 2 are driven by the understanding that the in-stream construction phase of the restoration represents a significant, albeit temporary, disturbance to the stream. We expect mean EPT richness (Ephemeroptera, Trichoptera, and Diptera) to decrease after the construction phase in response to disturbance (McCabe et al. 2000). Invertebrate density has shown to change unpredictably to disturbance so we chose to report changes without making a priori predictions. As the restored stream reaches equilibrium, the restoration response should indicate an increase in stream condition as wetted area of LWD has been shown to increase macroinvertebrate diversity and density (Vannotte et al. 1980). Studies suggest overall taxa richness may increase in response to increased physical habitat heterogeneity, but overall EPT richness and invertebrate density remains unaffected (Hilderbrand et al. 1997 and Miller et al. 2009). Families in the Diptera order are known to be tolerant to disturbance because of their generalized feeding and habitat preferences (Wallace 1996). Additionally, Dipterans are highly fecund and undergo many generations per year (Merrit and Cummins 1996). We expect the density of Dipterans will increase immediately after the construction phase and decrease as the restored stream reaches equilibrium.

Table 2. Summary of predicted macroinvertebrate responses to restoration at Rock Creek in the Portland metropolitan area of Oregon.

\begin{tabular}{|l|ccr|}
\hline Metric & F14 & S15 & Rationale \\
\hline Mean taxa richness & $\downarrow$ & $\uparrow$ & McCabe et al. 2000 \\
Mean invertebrate density & - & - & Miller et al. 2007 \\
Mean FFG diversity score & $\downarrow$ & $\uparrow$ & Barbour et al. 1996 \\
Mean OWEB IBI score & $\downarrow$ & $\uparrow$ & OWEB 1999 \\
Mean long-lived density & $\downarrow$ & $\uparrow$ & Huryn et al. 2003
\end{tabular}


Mean short-lived density

Mean Diptera density
Pecarsky et al 1993

Wallace 1996

Table 2: Predicted macroinvertebrate community responses to restoration at Rock Creek. Fall 2014 represents 6 months post-restoration and spring 2015 represents one year postrestoration. An up arrow indicates an increase in that metric from the previous sampling period. A down arrow indicates a decrease in that metric from the previous sampling period.

Disturbance dynamics have been shown to play a major role in functional attributes of benthic macroinvertebrate communities. To examine functional changes in response to restoration in our study, we chose to look at feeding groups and life cycles. Distribution of functional feeding groups in macroinvertebrate communities is known to reflect process-level attributes in small streams, making it useful for tracking ecological responses to disturbance (Rawer-Jost et al. 2000). We predict that diversity of functional feeding groups will be diminished after the construction phase as specialized feeders have been shown to be more sensitive to disturbance than generalists (Barbour et al. 1996). Life history attributes are shown to be highly related to reach-scale physical features, suggesting a strong relationship to local environmental conditions (Richards 2003). A study by Huryn et al. (2000) suggests productivity in disturbed streams is driven by rapid growth rates instead of high biomass, favoring small but fast developing organisms. We predict the density of long-lived organisms will decrease following the construction period, and increase as the restored stream reaches equilibrium. Conversely, we predict the density of short-lived organisms will increase following the construction period and decrease as the restored stream reaches equilibrium.

We chose to include the Oregon Watershed Enhancement Board's (OWEB) Level 2 Index of Biotic Integrity (IBI) as a summary metric because it is sensitive to organic pollution and regionally specific (OWEB 1999). The OWEB IBI summarizes some of the metrics included in this study into one number that represents the condition of the stream. The higher the OWEB IBI score, the less impairment detected in the stream. We predict the OWEB IBI score will decrease immediately after the construction phase, and increase as the stream reaches equilibrium. 
According to McCabe (2000), changes in macroinvertebrate density and abundance in response to physical disturbances including stones being overturned, scraped or scoured can be detected between 15 and 420 days after the disturbance event. The in-stream construction phase of the restoration project at Rock Creek lasted from spring to summer 2014, and thus most macroinvertebrate responses should be detectable in spring 2015.

\section{Results}

\subsection{Sampling effort variability}

High school students from NCSD visited Rock Creek, while PSU undergraduates visited Balch Creek exclusively. The quantity of NCSD students enrolled in the WHEP program permitted us to schedule more field trips per season at Rock Creek than Balch Creek. Balch Creek was always visited twice per season, but Rock Creek was visited up to four times per season. High school groups had greater class sizes and more study groups than university groups. As a result, both the number of replications and the area sampled was greater at Rock Creek than Balch Creek, representing a source of sampling effort variability (Table 3 ).

Table 3. Summary of total student sampling effort at Balch Creek and Rock Creek in the Portland metropolitan area of Oregon between 2011-2015.

\begin{tabular}{l|rr|}
\hline Metric & Balch & Rock \\
\hline Number of students & 292 & 896 \\
Number of field trips & 16 & 23 \\
Mean number of groups per season & $10( \pm 1.6)$ & $32.1( \pm 9.8)$ \\
Area sampled $\left(\mathrm{ft}^{2}\right)$ & 83 & 142 \\
Number of samples & 83 & 142 \\
\hline
\end{tabular}


Table 3: Summary of student sampling effort at Balch Creek and Rock Creek between 2011-2015. A sample is defined as the data generated by one student group and represents a randomly sub-sampled $1 \mathrm{ft}^{2}$ of benthos.

Differences in overall sampling effort were reflected in the total number of organisms collected from each stream over the course of this study; 1798 at Balch Creek and 5972 at Rock Creek. To show the difference between macroinvertebrate communities at Rock Creek and Balch Creek, we reported mean community metrics and variance at both creeks before the restoration construction phase at Rock Creek. During this period, the mean count of macroinvertebrates per $1 \mathrm{ft}^{2}$ sample was 21.6 at Balch Creek and 42.1 at Rock Creek. Balch Creek had a greater mean richness, FFG diversity score, OWEB IBI score and mean long-lived density than Rock Creek. Throughout the study period, Rock Creek had a greater mean invertebrate density, mean short-lived density and mean Diptera density than Balch Creek. It should be noted that standard deviation was greater at Rock Creek for all metrics except for mean taxa richness and mean short-lived density for the duration of this experiment.

Table 4. Summary of pre-restoration data collected from Balch Creek and Rock Creek in the Portland metropolitan area of Oregon from 2011-2014.

\begin{tabular}{|l|rr|}
\hline Metric & Balch & Rock \\
\hline Macroinvertebrates counted & 1172 & 3296 \\
Mean EPT richness per sample & $10.8( \pm 1.2)$ & $11( \pm 1.2)$ \\
Mean invertebrate density per sample & $22.2( \pm 4.3)$ & $30( \pm 11.3)$ \\
Mean FFG diversity score per sample & $0.6( \pm 0.1)$ & $0.3( \pm 0.1)$ \\
Mean OWEB IBI score per sample & $19.6( \pm 0.9)$ & $20( \pm 3.2)$ \\
Mean long-lived density per sample & $1.9( \pm 1.7)$ & $1.1( \pm 1.1)$
\end{tabular}


Mean short-lived density per sample

Mean Diptera density per sample
$20.3( \pm 7.0)$

$2.5( \pm 1.6)$
$20.2( \pm 8.1)$

$0.9( \pm 0.3)$

Table 4: Summary of pre-restoration invertebrate data at Balch Creek and Rock Creek between 2011-2015. Means are presented as averages per sample over the entire study period.

Table 4 shows differences in baseline pre-restoration conditions at Rock and Balch Creeks. On average, Balch and Rock Creek exhibited similar trends for most of these metrics during this period. One example of a substantial difference would be in the mean functional feeding group diversity index score per sample, which was 0.3 at Rock Creek and 0.6 at Balch Creek. As the score ranges from zero to one, this result suggests a greater connectivity in the food web at Balch Creek when compared to Rock Creek during this period. We chose to include only pre-restoration data for this table because it also illustrates the differences in variance between our two student groups. If high school and college students did not perform at a similar level in terms of sampling error and bias, we would expect standard deviations to be greater at one stream.

3.2 Temporal patterns 
We created line graphs to show how the macroinvertebrate communities at Balch Creek and Rock Creek changed throughout the study period. In order to test our predictions, we wanted to show if any of these metrics fell outside of the prerestoration range of variability after the construction phase was completed. If a given metric exceeded the pre-restoration maximum or minimum at either stream, we interpreted this as a detectable response to restoration in student collected data. Table 5 is a summary of these conclusions over the study period.

Table 5. Summary of post-restoration macroinvertebrate monitoring outcomes at Balch and Rock Creek.

\begin{tabular}{l|ccr|}
\hline Metric & \multicolumn{1}{c}{ Balch } & Rock & Prediction \\
\hline Mean taxa richness & $\mathrm{N}$ & $\mathrm{Y}$ & Confirmed \\
Mean invertebrate density $\left(n / \mathrm{ft}^{2}\right)$ & $\mathrm{N}$ & $\mathrm{Y}$ & Confirmed \\
Mean FFG diversity score & $\mathrm{N}$ & $\mathrm{N}$ & Unconfirmed \\
Mean OWEB IBI score & $\mathrm{N}$ & $\mathrm{Y}$ & Confirmed \\
Mean long-lived density $\left(n / \mathrm{ft}^{2}\right)$ & $\mathrm{Y}$ & $\mathrm{Y}$ & Unconfirmed \\
Mean short-lived density $\left(n / \mathrm{ft}^{2}\right)$ & $\mathrm{Y}$ & $\mathrm{Y}$ & Unconfirmed \\
Mean Diptera density $\left(n / \mathrm{ft}^{2}\right)$ & $\mathrm{N}$ & $\mathrm{Y}$ & Confirmed \\
\hline
\end{tabular}

Table 5: Post-restoration monitoring outcomes in terms of pre-restoration maximum and minimum exceedance as of spring 2015. An " $\mathrm{N}$ " indicates that metric failed to exceed the pre-restoration range of variability. A " $Y$ " indicates that metric did exceed the pre-restoration range of variability. The right column indicates whether or not these results confirmed our apriori predictions. 


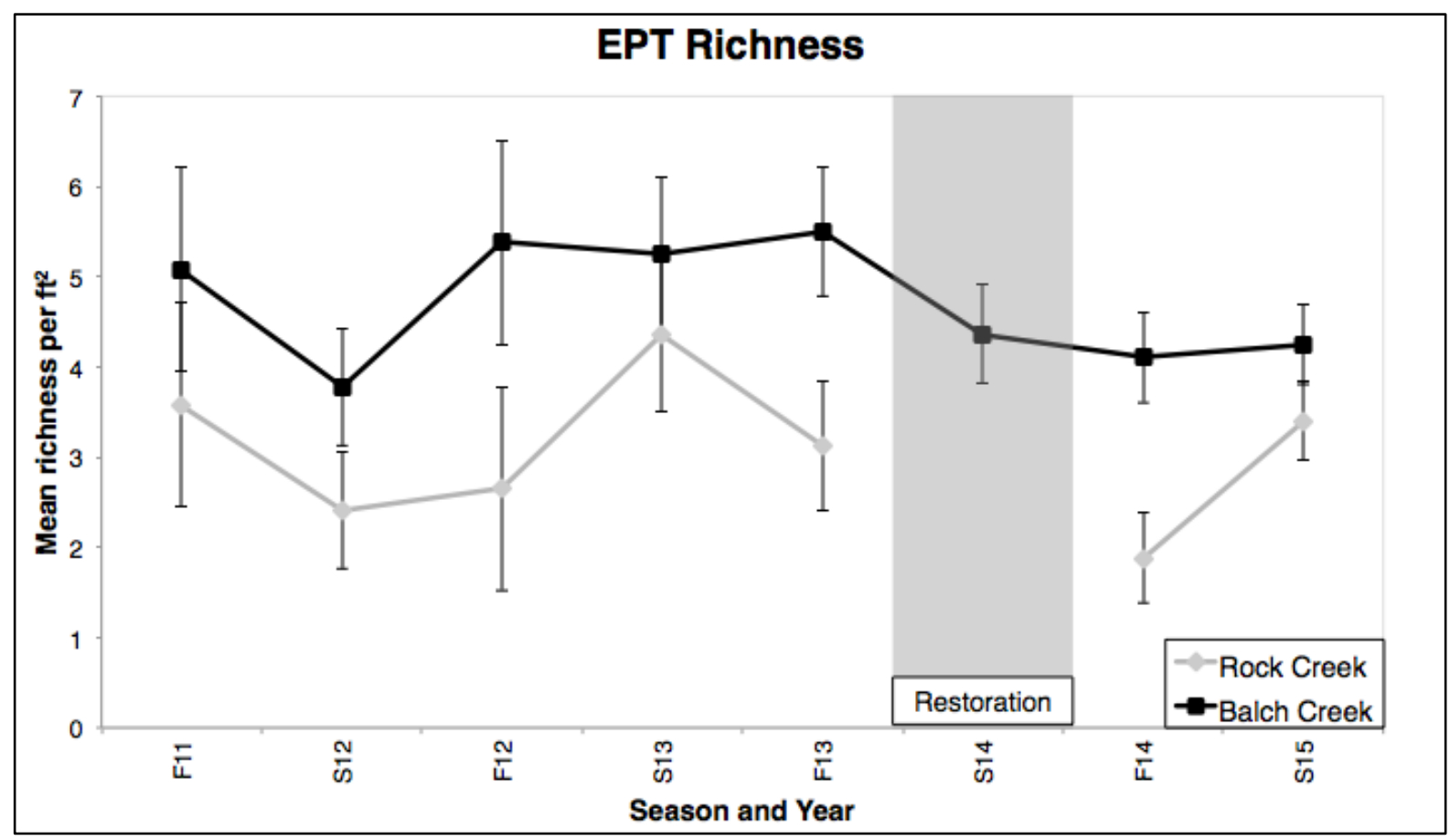

Figure 3: Mean EPT richness per square foot sample at Rock Creek and Balch Creek from fall 2011 to spring 2015. The black and grey lines represent Balch and Rock Creek, and the shaded area represents the construction phase of the restoration project. Error bars signify standard deviation.

During the study period, Rock Creek had a lower mean EPT richness than Balch Creek, but both reaches followed a similar pattern. Overall, Balch Creek exhibited a mean of 6.3 EPT taxa per $\mathrm{ft}^{2}$, while Rock Creek exhibited an average of 5.6 EPT taxa per $\mathrm{ft}^{2}$. Changes in EPT richness after the restoration project on Rock Creek are shown in Figure 3 and can be interpreted as a weak macroinvertebrate response to restoration. Before the construction phase, EPT richness peaked at 4.3 families per $\mathrm{ft}^{2}$ at Rock Creek. Six months after the restoration project on Rock Creek, mean EPT richness reached its lowest point of the study period at 1.9 families per sample. As of spring 2015, EPT richness on Rock Creek had increased to 3.1 families per sample, within the pre-restoration range of variability (Figure 3). Balch Creek exhibited a similar trend during the study period, suggesting regional trends may drive variance in the Rock Creek data. 


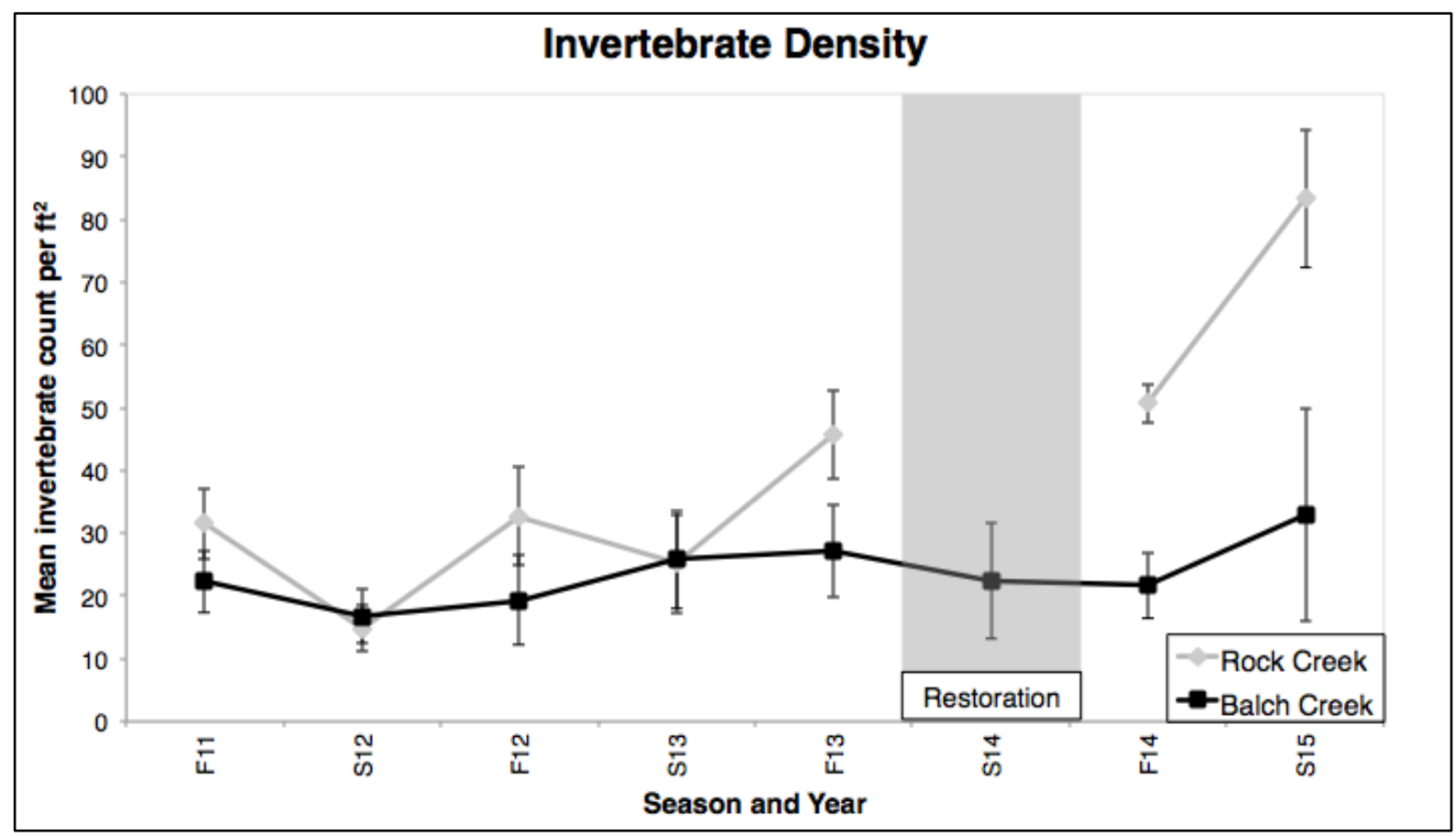

Figure 4: Mean invertebrate density per square foot sample at Rock Creek and Balch Creek between fall 2011 and spring 2015. The black and grey lines represent Balch and Rock Creek, and the shaded area represents the construction phase of the restoration project.

During the study period, total invertebrate density at Rock Creek exhibited a strong response to the restoration project (Figure 4). On average, Rock Creek tended to exhibit a higher invertebrate density throughout the study period; Balch Creek had an average of 22 invertebrates per $\mathrm{ft}^{2}$, while Rock Creek had an average of 42 invertebrates per $\mathrm{ft}^{2}$. Before the restoration construction, mean invertebrate density peaked at 45 invertebrates per $\mathrm{ft}^{2}$. After the restoration was completed, mean invertebrate density at Rock Creek increased to a peak of 83 specimens per sample, far outside the pre-restoration range of variability. Balch Creek exhibited less variance in average invertebrate density during this study. Standard deviation in invertebrates per $\mathrm{ft}^{2}$ was 22.4 at Rock Creek and only 5 at Balch Creek. Most of the variance in invertebrate density at Rock Creek occurred after the construction phase, suggesting a strong invertebrate response to the restoration activities at Rock Creek. 


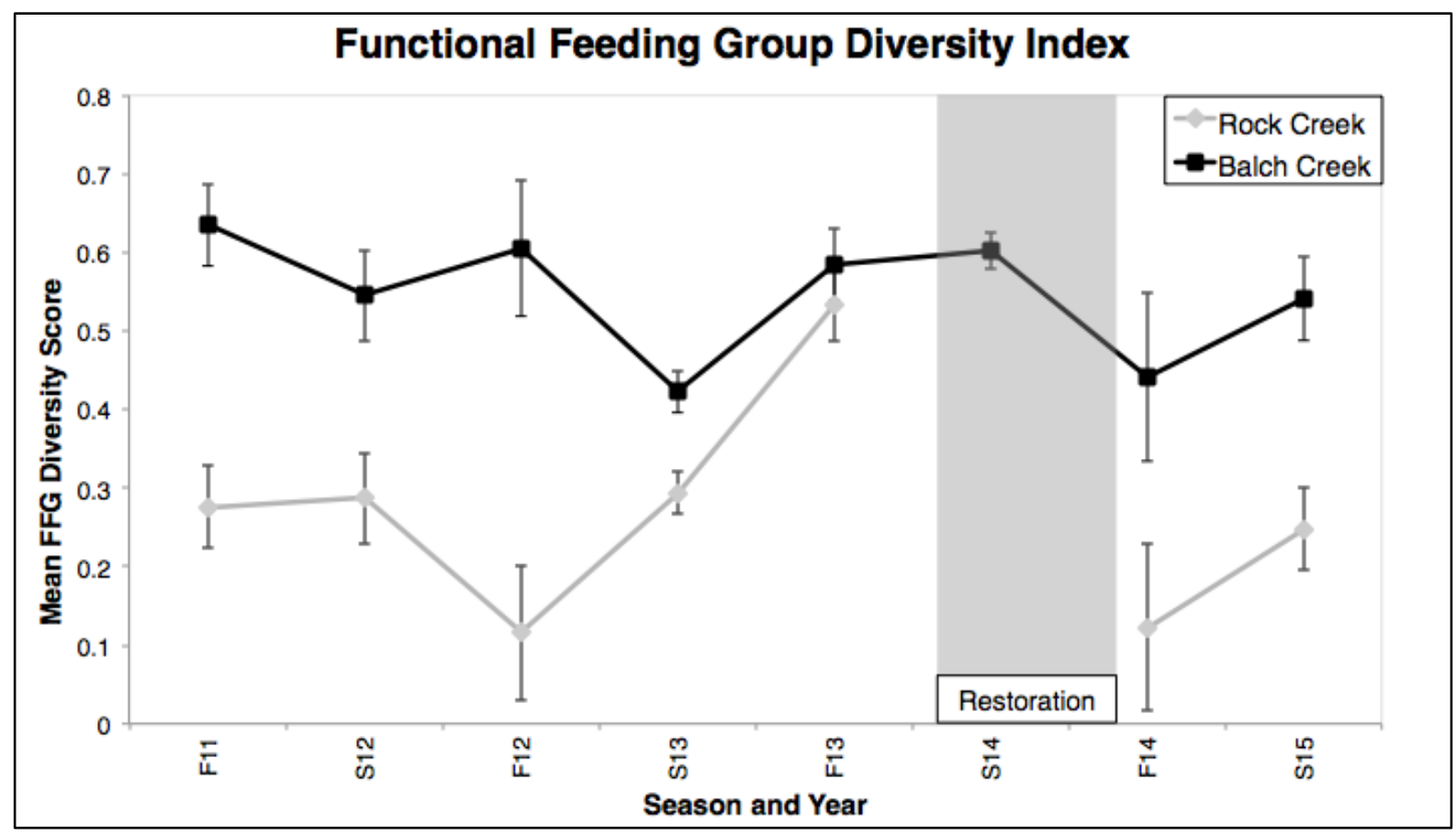

Figure 5: Inverse Simpson's Diversity Index score of functional feeding groups at Rock Creek and Balch Creek from fall 2011 to spring 2015. The black and grey lines represent Balch and Rock Creek, and the shaded area represents the construction phase of the restoration project.

Balch Creek exhibited smaller variation in diversity of functional feeding groups (FFG) than Rock Creek throughout the study period. Overall, Balch Creek had a higher FFG diversity score throughout the study period, with an average of 0.6 compared to a score of 0.2 at Rock Creek. The overall standard deviation in functional feeding group diversity scores was 0.04 at Balch Creek and 0.11 at Rock Creek for the entire data set. In fall 2014, Rock Creek's FFG diversity reached a score of 0.1 , slightly within the pre-restoration range of variability. In spring of 2015, FFG diversity at Rock Creek increased to 0.19 , within the pre-restoration variability range (Figure 5). Balch Creek exhibited a more stable pattern in FFG diversity, reaching its lowest score of 0.55 in spring of 2015. Both creeks failed to exceed their pre-restoration minimum and maximum FFG diversity scores after the restoration was completed leaving our prediction unconfirmed by $\mathrm{BACl}$ design. 


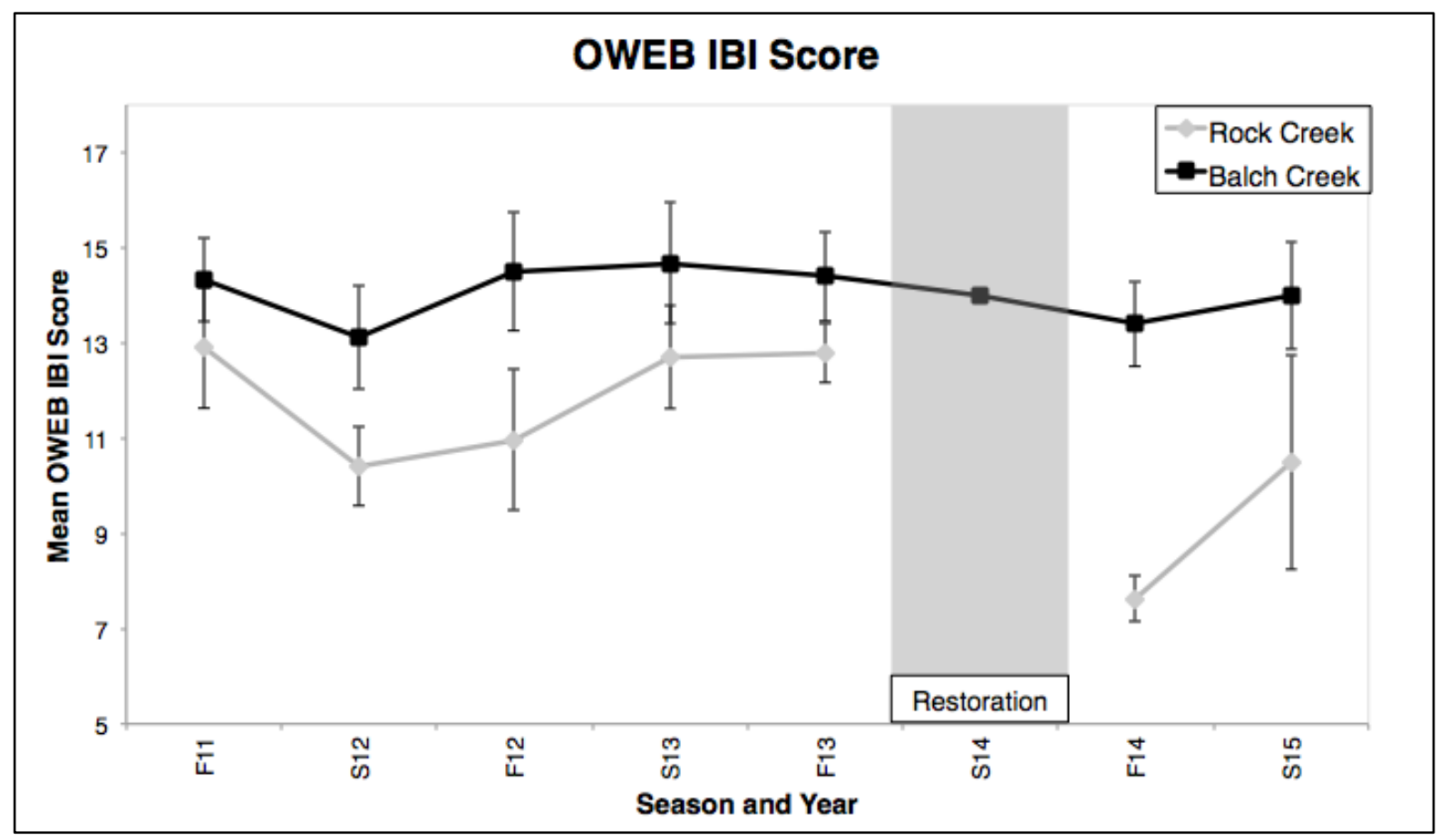

Figure 6: Calculated OWEB Index of Biotic Integrity (IBI) scores of Balch Creek and Rock Creek from fall 2011 to spring 2015. The black and grey lines represent Balch and Rock Creek, and the shaded area represents the construction phase of the restoration project.

Balch Creek exhibited smaller variation in mean OWEB IBI scores than Rock Creek during our study, ranging from 13.1 to 14.7. Rock Creek's IBI score ranged from 10.4 to 12.9. In terms of group level, non-averaged scores, Rock Creek occupied all three impairment categories over the course of this study. Standard deviation in mean OWEB IBI scores was 0.5 at Balch Creek and 1.9 at Rock Creek. Standard deviation at Rock Creek was highest at Rock Creek in spring of 2015, reaching a peak of 2.253. After the restoration project was completed, Rock Creek's mean IBI score was 7.6, followed by a score of 10.5 in spring 2015 (Figure 6). The $\mathrm{IBI}$ score at Rock Creek was lowest post-restoration, exceeding the pre-restoration minimum. The post-restoration OWEB IBI score did not exceed the pre-restoration range at Balch Creek. At Balch Creek, the mean OWEB IBI score remained within the pre-restoration range of variability from fall 2012 through fall 2014 . Using our $\mathrm{BACl}$ design, this suggests the variance in Rock Creek was not due to regional trends. 


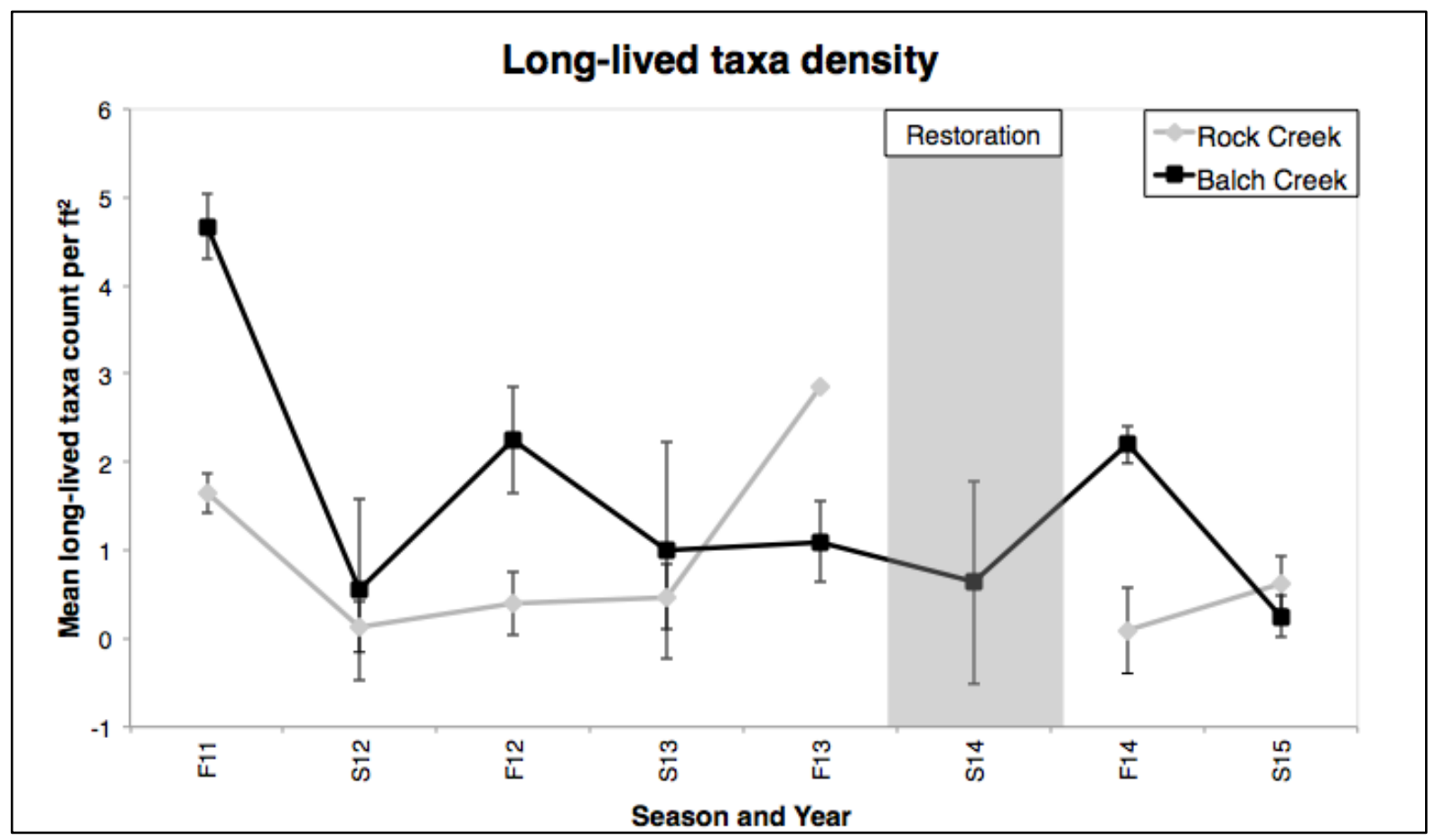

Figure 7: Mean abundance of long-lived taxa per square foot in Balch Creek and Rock Creek from fall 2011 to spring 2015. The black and grey lines represent Balch and Rock Creek, and the shaded area represents the construction phase of the restoration project.

Density of long-lived taxa, including many of the Plecoptera and Trichoptera families was highly variable at both Balch Creek and Rock Creek throughout the study period. The variance in long-lived taxa density was lower at Rock Creek than at Balch Creek, with values of 1.4 and 1.0 respectively. At Rock Creek, the standard deviation of 1.0 was greater than the mean of 0.9 throughout the study period. Balch Creek had a greater density of long-lived organisms than Rock Creek in every season expect fall 2013, where Rock Creek experienced its highest mean of 2.9 long-lived organisms per sample. Directly after the restoration was completed, Rock Creek displayed its lowest mean of 0.1 long-lived organisms per sample, representing a distinct change from season to season. The spring 2015 data point of 0.6 long-lived organisms per sample fell within the pre-restoration range of variability at Rock Creek (Figure 7). At Balch Creek, we found long-lived taxa density increased during the fall 2013 - fall 2014 interval, suggesting a macroinvertebrate response to restoration at Rock Creek. 


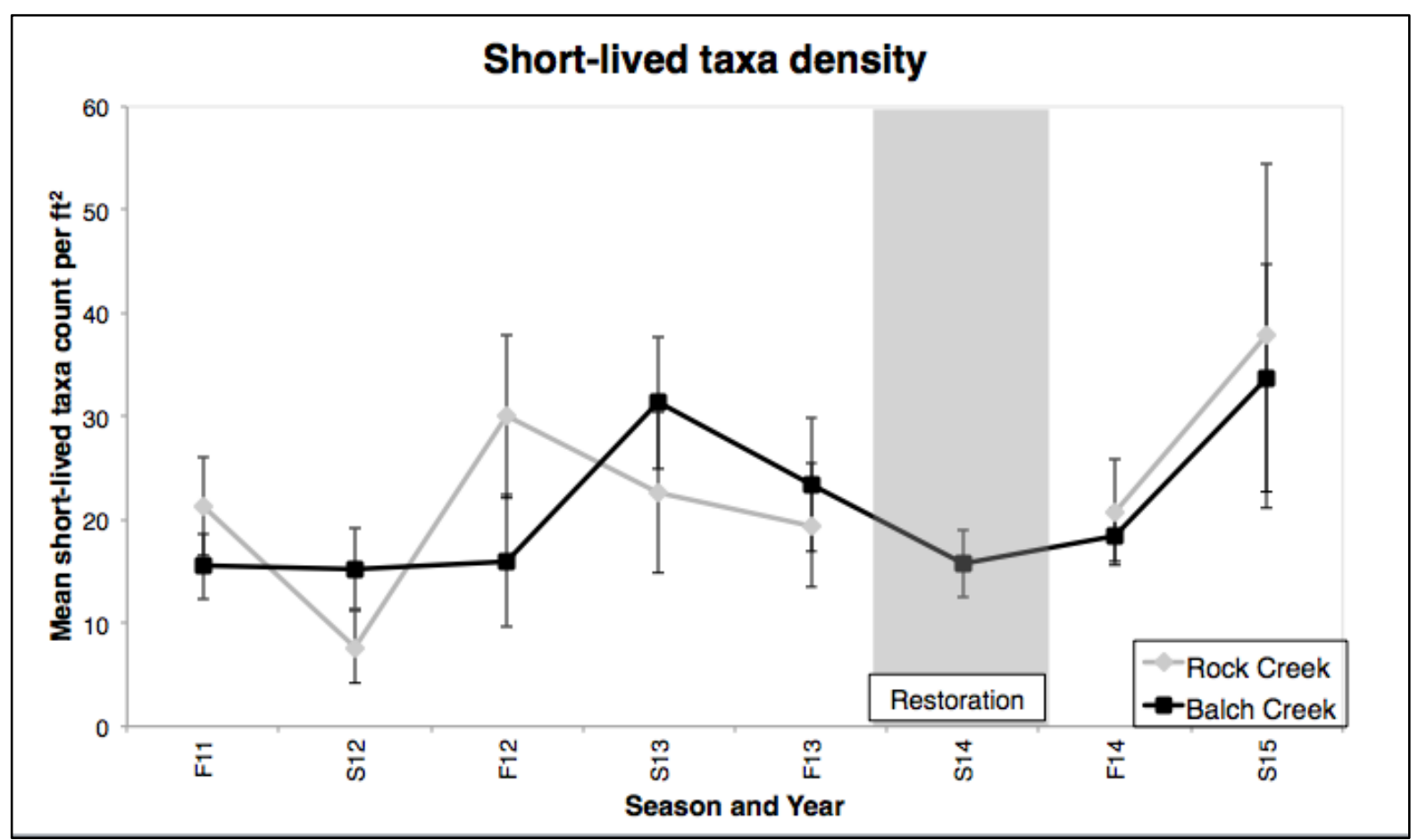

Figure 8: Mean abundance of short-lived taxa per $\mathrm{ft}^{2}$ sample in Balch Creek and Rock Creek from fall 2011 to spring 2015. The black and grey lines represent Balch and Rock Creek, and the shaded area represents the construction phase of the restoration project.

Rock Creek and Balch Creek exhibited a relatively similar pattern of mean short-lived taxa density throughout the study period, when compared with other metrics. The mean short-lived density was 21.2 organisms per $\mathrm{ft}^{2}$ at Balch Creek and 22.8 organisms per $\mathrm{ft}^{2}$ at Rock Creek. Overall standard deviation was 7.5 at Balch Creek and 9.4 at Rock Creek during the study period. Both Rock Creek and Balch Creek experienced maximum short-lived taxa density in spring 2015. Balch Creek had a smaller range of variability than Rock Creek, which ranged from 7.7 to 37.9 short-lived organisms per sample. Short-lived density at Rock Creek increased slightly directly after the restoration project. At Balch Creek, short-lived taxa density slightly decreased during the same one-year interval from fall 2013 to fall 2014. However, in spring 2015 short-lived density increased greatly at both Rock Creek and Balch Creek (Figure 8). Since Balch Creek and Rock Creek both exhibited similar patterns in short-lived taxa density, it seems likely that changes seen at Rock Creek are not in direct response to restoration activities. 


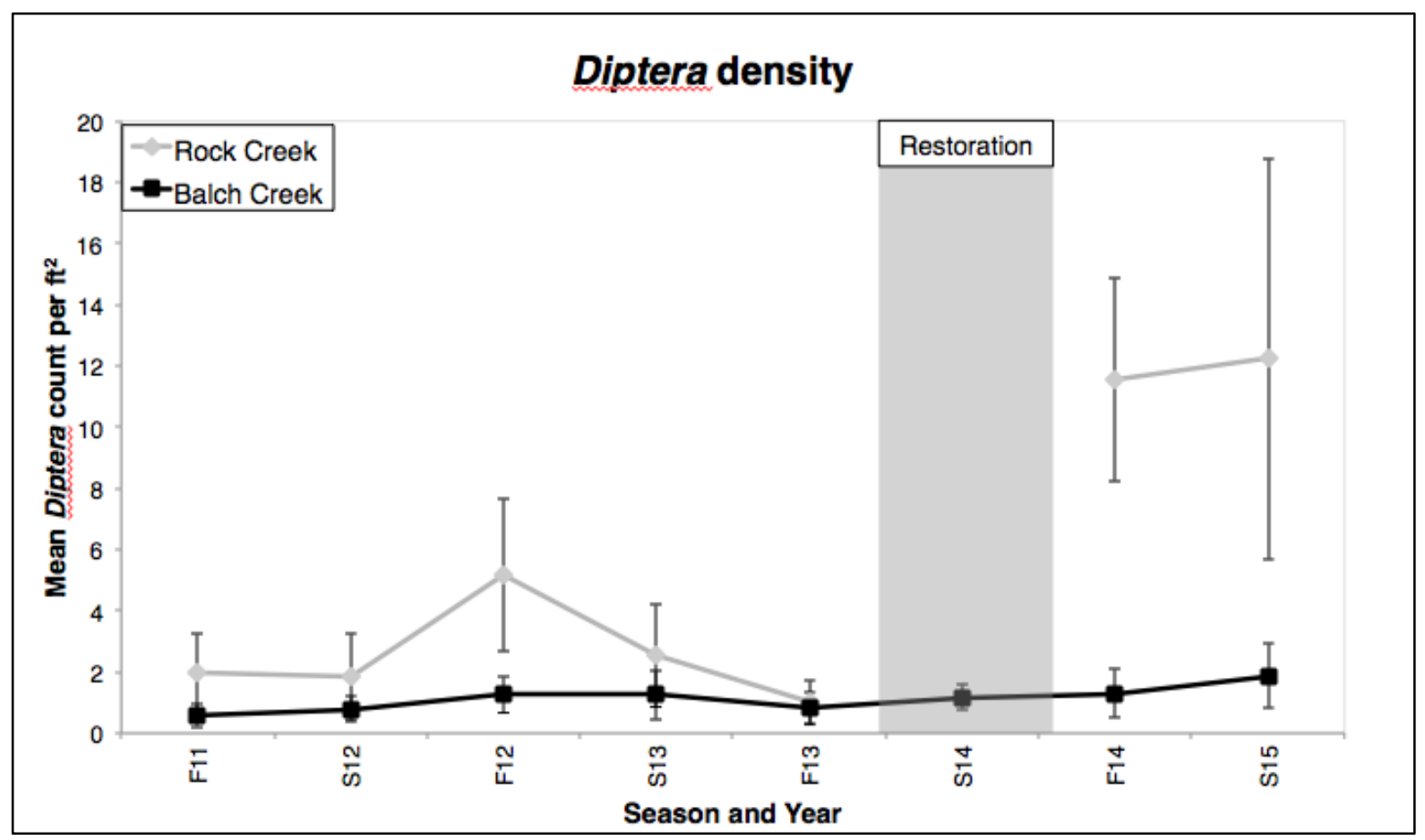

Figure 9: Mean abundance of Diptera per square foot sample in Balch Creek and Rock Creek from fall 2011 to spring 2015. The black and grey lines represent Balch and Rock Creek, and the shaded area represents the construction phase of the restoration project.

In every season except for fall 2013, Rock Creek exhibited a greater density of Diptera per $\mathrm{ft}^{2}$. The overall mean density of Diptera was 1.1 organisms per $\mathrm{ft}^{2}$ at Balch Creek and 5.1 organisms per $\mathrm{ft}^{2}$ at Rock Creek. During our study period, Balch Creek never experience more than 1.9 Dipterans per sample. The standard deviation of Diptera density was much higher at Rock Creek than at Balch Creek, with values of 4.8 and 0.4 respectively. After the restoration construction phase completed on Rock Creek, the mean density of Diptera was more than twice as high as its pre-restoration maximum. Rock Creek's mean Diptera density continued to increase into spring 2015, where it peaked at 12.2 Dipterans per sample (Figure 9). Changes in Diptera density at Rock Creek were among the most substantial responses to restoration in our study. Since Diptera density was relatively stable at Balch Creek throughout the study period, it seems likely that the pattern seen at Rock Creek is in response to the restoration activities and not external regional trends. 
Results of this experiment suggest that student macroinvertebrate data can detect ecological trends in streams following restoration activities. Variability and bias in sampling effort and the field method did not prevent detection of differences among study reaches and changes between seasons. These results support the use of Citizen Science to track macroinvertebrate responses to in-stream restoration. Of the six a priori predictions shown in Table 2, 4 were supported by our data. High productivity in the short-lived taxa such as Diptera was a major source of the variability in invertebrate density seen at post-restoration Rock Creek.

Our results regarding changes in EPT richness, FFG diversity, OWEB IBI scores, and long-lived taxa density in response to the restoration project on Rock Creek indicate that the macroinvertebrate community was responding to disturbance during the construction phase of the restoration project. Our results suggest that total invertebrate density, short-lived taxa density and Diptera density at Rock Creek increased in spring 2015, and that the invertebrate community had considerably shifted after the restoration was completed. However, it is important to note that only one year elapsed since the restoration project was finished as of spring 2015 , which is not enough time for several long-lived taxa to reproduce, including members of the Plecoptera order. Our results suggest more time is needed for macroinvertebrate production at Rock Creek to reach post-project equilibrium. The data generated by WHEP students is thus capable of detecting coarse ecological trends, but insufficient time has elapsed since the restoration project was completed to draw any conclusions on restoration effectiveness.

Our results suggest students can act as a proxy for citizen scientists to monitor family-level invertebrate richness and density at reach-scale restoration sites with some limitations. One major limitation with the WHEP program is its dependence on experienced taxonomists. Generation of student data still depends on validation by experienced taxonomists and thus the WHEP program is not an example of independent Citizen Science. That being said, the WHEP program is generating data that can detect macroinvertebrate responses to restoration at a 
lower cost than professional consultants. Additionally, the WHEP program presents Clackamas County an opportunity for stacking functions, i.e., generating biological data while meeting public outreach goals. In situations where professionally collected pre- and post-project biological monitoring data is unavailable, data collected by WHEP students may be used for basic restoration effectiveness monitoring. Additionally, WHEP data may be a low-cost alternative for small restoration projects that cannot budget for professional effectiveness monitoring. Finally, WHEP invertebrate data collected from other streams in the lower Clackamas Basin, i.e., Mt. Scott Creek, Carli Creek, or Clear Creek have potential as sources of pre-project monitoring data for future restoration effectiveness studies.

\section{Recommendations}

As stated earlier, the presence of an experienced taxonomist is required to generate usable data from the WHEP program as it is designed, meaning it is not a true example of Citizen Science. To overcome this challenge, I recommend a mentor program, whereby skilled students and/or teachers could function in place of experienced taxonomists in order to validate data from students in the future. For example, if a particular student group displayed a talent for identifications and an interest in continiuing the practice, they could be invited to a workshop that would train them to the point where they could correctly identify and validate invertebrate family identifications for the next season. This would provide selected students with advanced taxonomy training and potentially eliminate the need for professionals to validate each student group's data. Qualifying students could be offered a stipend or a work study position to incentivize them to donate time to the WHEP program. If students were able to be trained sufficiently, perhaps they could supervise future field trips to create a truly self-sufficient Citizen Science program.

We should also renew our efforts to train teachers in macroinvertebrate identification techniques. If teachers enrolled in the WHEP program were more confident in invertebrate identification, they may be able to verify student data sheets 
in leiu of an experienced taxonomist. This would allow us to gather more data in cases where a taxonomist may not be available. I recommend a annual teacher workshop be held at Clackamas High School where teachers can use microscopes to magnify key identification features of the different invertebrate families we expect to catch. We could conclude this workshop with a basic taxonomy exam to see if teachers are improving their identification skills from year to year.

A persistent challenge to generating usable monitoring data from students or volunteers is variation sampling effort and bias. As this project is grounded in public outreach, controlling for sampling effort was not the top priority. The structure of WHEP field trips meant that most teachers would involve several classes per season; meaning study sites would sometimes be visited multiple days in a row. Repeating field trips in this short period of time meant that some students collected drift samples from areas that had already been disturbed, because students had no way of knowing which riffles had been sampled by previous classes. In some cases, insufficient time may have elapsed to enable recolonization by drift, affecting invertebrate richness and density as measured in this report (Waters 1962, Brittain 1998 and Milner 2008). One potential solution to this problem would be to only consider invertebrate data from the first field trip of the season, or try to schedule staggered field trips to allow for recolonization to occur. However, applying this method to the 2011-2015 WHEP data did not change conclusions that were drawn, suggesting frequency of sampling the same riffle is not a major source of variability in our study.

When interpreting a long-term macroinvertebrate data, there is a need to consider environmental data that may explain coarse trends in stream productivity. For this reason, I recommend WHEP instructors include remarks on recent weather events and take photos of study sites each sampling season. These notes should be coupled with physical data such as flow and water temperature from USGS gauges wherever possible to help explain macroinvertebrate community variability.

Generating macroinvertebrate data with high school or college students requires a high level of coordination between teachers, students, and scientists. 
Teachers were more concerned with providing students with a field-based inquiry opportunity, and students more concerned with socializing or receiving credit than collecting reliable invertebrate data. This is an example of friction between group goals found in other studies (Nerbonne and Vondracek 2003). In order for teachers to be willing to coordinate with scientists to collect data, some incentive must be presented. In this study, a small stipend was offered to teachers, along with reimbursement of transportation costs. I recommend this stipend should continue to be offered to teachers, and perhaps increased if teacher enrollment begins to drop. I also recommend that more efforts be made to raise WHEP visibility to other teachers in the district. Teacher recruiting is currently based mostly on word-ofmouth so we may be able to expand the program to include other teachers if there were a bigger online presence, similar to the Clackamas River Basin Council's Water Education Team website.

Another challenge to using WHEP students for restoration effectiveness monitoring is gathering pre-restoration data. While this problem is common amongst all restoration projects, it is especially difficult when considering the amount of planning that must be done to coordinate a high school field trip unit. Sites that are candidates for restoration will almost certainly have invasive plant species in the riparian zone that may severely impair access to riffle areas. To overcome this challenge, increased communcation between WES and WHEP staff is recommeded. For example, WES employees who focus on restoration projects instead of public outeach could be invited to the annual WHEP meetings in order to forecast stream restoration projects that might be funded in the future. This way, WHEP staff and NCSD teachers could be informed of potential field trip opportunities for the next sampling season or academic year.

Expanding the WHEP to include restoration monitoring could benefit teachers and students and increase visibility of the program. The WHEP is made attractive to teachers because WHEP instructors present watershed health curriculum to students that would address Science, Teaching, Engineering and Math (STEM) teaching standards. The WHEP curriculum should be modified to reflect the 
opportunity for restoration effectiveness monitoring. Currently, the curriculm focuses mainly on watershed-scale land-use comparisons between urbanized and forested streams. If we are taking students to restoration sites to collect data, I recommend including curriculum on restoration goals and practices as well as a background on the history of stream restoration in the United States.

My final recommendation is that WES continues to fund the WHEP grant as it has demonstrated to fulfill multiple needs of the county. This report shows students are capable of generating data that can detect ecological trends following restoration activities. These data represent a source of supplementary restoration effectiveness monitoring at no extra cost to the county. Additionally, the WHEP is generating a long-term benthic macroinvertebrate dataset, which is intrinsically valuable on its own. Since the WHEP program is able to stack functions on a single grant, it should help WES justify its budget to Clackamas County. Funding gaps that prevent sampling are especially detrimental to long-term data sets such as these and should be avoided. If WES were to consider funding additional field trips with the restoration budget, we could expand our data coverage and include more students in the process.

References

1) Auditor's Office (2005). Actions for Watershed Health, 2005 Portland Watershed Management Plan Implementation. City of Portland.

2) Bailey, R., Norris, R., and Reynoldson, T. (2001) Taxonomic resolution of benthic macroinvertebrate communities in bioassessments. Journal of the North American Benthological Society 20(2): 280-286

3) Barbour MT, Gerritsen J (1996) Subsampling of benthic samples: A defense of the fixed-count method. Journal of the North American Benthological Society 15(3): 386-391 
4) Brittain JE, Eikeland TJ (1988) Invertebrate drift: A review. Hydrobiologia 166: 77-93

5) Bureau of Environmental Services (2008). Wildlife Communities. Willamette Subwatershed: Balch. City of Portland.

6) Clackamas County Water Environment Services (2012) Clackamas County Service District \#1. Rock Creek Conceptual Site Plan and Management Plan.

7) Clackamas County Water Environment Services. (2014) Clackamas County Service District \#1. Benthic Macroinvertebrate and Geomorphological Monitoring Report.

8) Cole M (2013) Lower Clackamas River Basin Macroinvertebrate Monitoring Plan. http://www.clackamasproviders.org/images/stories/13626_FINAL_Clack_Mon_Plan_6-17-13.pdf Accessed Feb 12, 2014

9) Edwards, P. (2005) Catch and Release Bioassessment. Volunteer Monitor Summer 2005.

10)Edwards, P. (2008) Stream insects of the Pacific Northwest. Center for Science Education. Portland State University.

11)Engel SM, Voshell JR (2002) Volunteer biological monitoring: Can it accurately assess the ecological condition of streams? American Entomologist 48: 164-177

12)Fore LS, Paulsen K, O'Laughlin $\mathrm{K}$ (2001) Assessing the performance of volunteers in monitoring streams. Freshwater Biology 46:109-123

13)Gleick, P. (2003) Global freshwater resources: soft-path solutions for the $21^{\text {st }}$ century. Science 302: 1524

14)Hilderbrand, R. H., Lemly, A. D., Dolloff, C. A., and Harpster, K. L. (1997) Effects of large woody debris placement on stream channels and benthic macroinvertebrates. Canadian Journal of Fisheries and Aquatic Sciences 54: 931-939

15)Huryn and Wallace (2000) Life history and production of stream insects. Annual Review of Entomology 45:83-110

16) Lepori et al. (2005) Does restoration of structural heterogeneity in streams enhance fish and macroinvertebrate diversity? Ecological Applications 15(6): 2060-2071 
17)Lester et al. (2007) Does adding wood to agricultural research streams enhance biodiversity? An experimental approach. Marine and freshwater research 58: 687-698

18) Levy, S (1998) Using bugs to bust polluters: volunteers delve into the secret life of streams. BioScience 48: 342-346

19)McCabe, J., Gotelli, N. (2000) Effects of disturbance frequency, intensity, and area on assemblages of stream macroinvertebrates. Oecologia 124: 270-279

20)Merritt and Cummins (2008) An introduction to the aquatic insects of North America. Kendall/Hunt Publishing Company. Dubuque, lowa

21)Miller et al. (2009) Quantifying macroinvertebrate responses to in-stream habitat restoration: applications of meta-analysis to river restoration.

Restoration Ecology 18(1): 8-19

22) Milner AM, Robertson AE, Monaghan K, Veal AJ, Flory EA (2008) Colonization and development of a stream assemblage over 28 years; Wolf Point Creek in Glacier Bay, Alaska. Frontiers in Ecology and the Environment 6: $413-419$

23) Nerbonne JF, Vondracek BC (2003) Volunteer macroinvertebrate monitoring: Assessing training needs through examining error and bias in untrained volunteers. Journal of the North American Benthological Society 22:152-163

24)OWEB (Oregon Watershed Enhancement Board) (1999) Oregon Watershed Assessment Manual. Prepared for the Governor's Watershed Enhancement Board, Salem, OR. Accessed on July $16^{\text {th }}, 2015$ at: (http://www.oweb.state.or.us/publications/wa_manual99.shtml)

25)OWEB (Oregon Watershed Enhancement Board) (2014) Oregon Effectiveness Monitoring Program. Accessed on July $16^{\text {th }}, 2015$ at: (http://www.oregon.gov/oweb/monitor/pages/effective_monitoring.aspx)

26)Palmer, M.A., Bernhardt, E.S. (2005) Synthesizing US river restoration efforts. Science 308: 636-637

27)Penrose, D., and Call, D. 1995. Volunteer monitoring of benthic macroinvertebrates: regulatory biologists' perspective. Journal of the North American Benthological Society 14: 203-209

28)Rawer-Jost C., Böhmer, J. (2000) Macroinvertebrate functional feeding group methods in ecological assessment. Hydrobiologia 422(423): 225-232 
29)Richards et al. (1997) Catchment and reach-scale properties as indicators of macroinvertebrate species traits. Freshwater Biology 37: 219-230

30)Roni et al. (2002) A Review of Stream Restoration Techniques and a Hierarchical Strategy for Prioritizing Restoration in Pacific Northwest

Watersheds, North American Journal of Fisheries Management, 22(1): 1-20

31)Roni et al. (2006) Rehabilitation of bedrock stream channels: the effects of boulder wier placement on aquatic habitat and biota. River Research and Applications 22(9): 967-980

32) Silvertown K (2009) A new dawn for citizen science. Trends in Ecology and Evolution 24(9): 467-471

33)USEPA (US Environmental Protection Agency) (1998) Introduction to the national directory of volunteer environmental monitoring programs. 5th Edition. EPA 841-B-98-009. US Environmental Protection Agency, Washington, DC.

34)Vannote et al. (1980) Habitat-specific responses of stream insects to land cover disturbance biological consequences and monitoring implications. Journal of North American Benthological Society 22(2): 292-307

35) Voshell et al. (1997) Effective and scientifically sound bioassessment: Opinions and corroboration from academe. Human and Ecological Risk Assessment: An International Journal, 3(6): 941-954

36) Wallace JB, Webster JR (1996). The role of macroinvertebrates in stream ecosystem function. Annual Review of Entomology 41: 115-39

37)Waters, $T$ (1962) Diurnal periodicity in the drift of stream invertebrates. Ecology 43(2): 316-320 